\title{
磁界によって配向した短繊維で強化したマイクロ部品の光造形* (短繊維を配向した薄膜の積層)
}

\author{
中本 剛*1, 览嶋 伸 弥*2
}

\section{Micro Part Reinforced by Addition of Unidirectional Short Fibers in Laser Photolithography by Applying Magnetic Field (Layered Thin Film with Aligned Short Fibers)}

\author{
Takeshi NAKAMOTO*3 and Shinya KOJIMA \\ ${ }^{* 3}$ Department of Mechanical Engineering, Graduate School of Engineering, Chiba University, \\ 1-33 Yayoi-cho, Inage-ku, Chiba-shi, Chiba, 263-8522 Japan
}

\begin{abstract}
The purpose of this research work is to produce micro part reinforced by unidirectional short fibers by laser photolithography. Ferromagnetic short fibers are added to liquid photopolymer. By applying magnetic field to this mixture, the axes of the short fibers are aligned along the direction of the magnetic field. Then, the photopolymer is solidified by the irradiation of UV laser in the desired shape. The solidified thin films with aligned short fibers are layered until the desired height is obtained. The surfaces of the solidified thin layers are observed by scanning electron microscope and the possibilities of the reinforcing effect between each layer are examined. Several examples of micro structure reinforced by unidirectional short fibers are produced by this method.
\end{abstract}

Key Words: Non traditional Machining, Machine Element, Micromachine, Reinforced Plastics Short Fiber, Laser Photolithography, Magnetic Field, Alignment

\section{1. 栟}

光造形法はマイクロサイズの構造物を製作する有力 な手段の一つであり，高アスペクト比（高さ/幅）を もつ部品から三次元形状の部品まで製作することがで きる(1) (4). しかし光造形法では，その素材は紫外線硬 化樹脂に限られる.このため，樹脂に粒子(お)（6)や短緎 維(7)（8)を混合して造形する研究が報告されている.こ れらの報告では，樹脂に混合する材料として短繊維を 使用する場合でも，短繊維を特定の方向にそろえてい ない.

著者らはこれまで，磁界によって長手軸方向をそろ えた短䋊維で強化したマイクロ部品を光造形法によっ て製作した，前報(のでは，造形を行うための装置と短 繊維の配向について検討し, 単一の層から成るマイク 口構造物を製作した。

* 原稿受付 2010 年 4 月 26 日.

*1 正員, 千葉大学大学院工学研究科(业 263-8522 千葉市稲毛 区弥生町 1-33).

*2 千葉大学大学院工学研究科.

E-mail : nakamoto@faculty.chiba-u.jp
ところで化学の分野では，磁界を利用して有機ナ， 結晶や短繊維を配向した材料の開発に関する研究が数 多く行われており (10) (13)，新分野一の応用も期待され ている. 本研究では, 配向した短繊維で強化した材料 の開発自体を目的とするのではなく，このような材料 からなるマイクロ部品を造形することを目的としてい る.

複合材料では，その機械的な特性の評価も重要な検 討課題である. 本研究のマイクロ部品では, 繊維強化 した樹脂の機械的な強度とともに, 積層した部品とし ての強度も調べなければならない.このためには, 単 一の樹脂層の強度だけでなく, 積層した樹脂の界面の 検討も必要になる.このように，短繊維を配向した樹 脂を積層した部品の造形，積層した樹脂の界面の検討， 造形した部品の強度試験を行わなければならない．

これら，連の研究課題のうち, 本報では, 配向した 短繊維からなる薄膜を積層して, マイクロ構造物を造 形する力法について述べる. 薄膜表面の電子顕微鏡観 察も行い, これにより積層界面の検討も行った. 最後 に, これらの結果を利用して, 実際にマイクロ部品の 


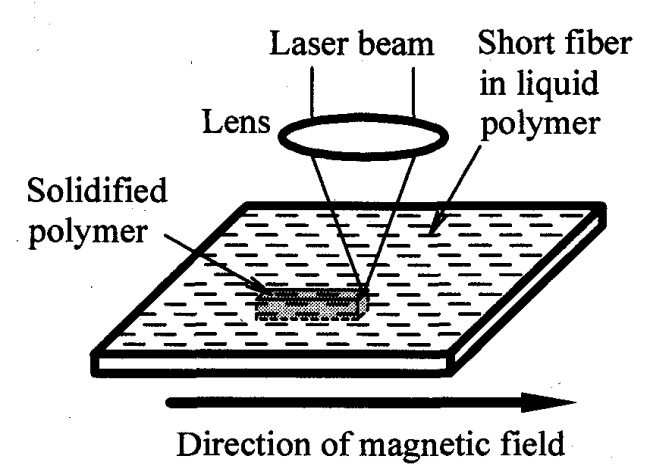

(a) Alignment of short fibers and solidification

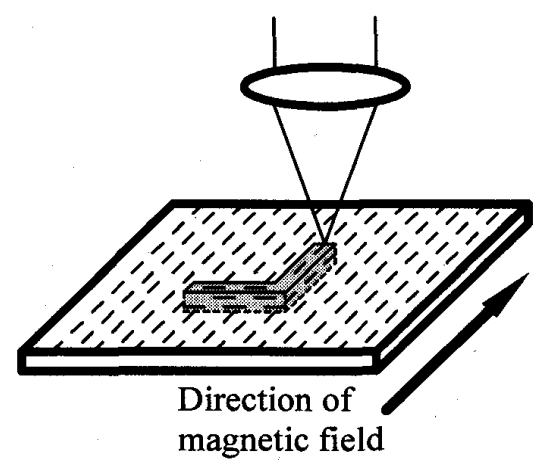

(b) Solidification along the second line

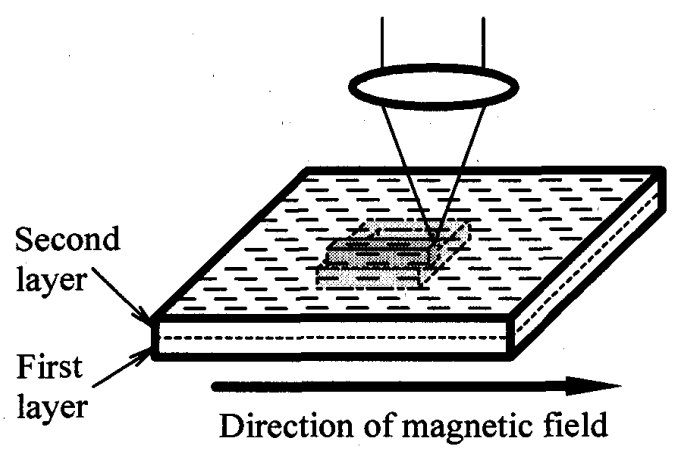

(c) Solidification on the second layer

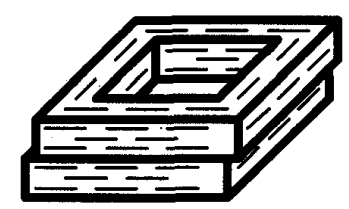

(d) Layered micro part reinforced by unidirectional short fibers

Fig. 1 Schematic diagram of manufacturing method

造形を行った.

\section{2 製作方法}

図 1 に製作方法の概略を示す，液体の柴外線硬化樹 脂と短繊維を混合する．短瀻維は磁界に応答するよう に，その素材は強磁性体とする。.この短䋊維と樹脂の 混合物を基板に薄く塗布する。この薄膜化した混合物 に対して例えば図1(引のように，左右方向に磁界を印 加することによって短䋊維の長手軸方向を左右の磁界 方向にそろえる.この状態で紫外線レーザービームを 所望の経路に沿って樹脂上で描画することによって樹 脂を硬化させる. 次に図 1(b)のように, 樹脂を紙面の 奥行き方向に磁界を印加することにより，この方向に 短瀻維をそろえる. この状態で同様にレーザービーム 描画によって，樹脂を硬化させる．このように，磁界 による短繊維の配向と樹脂の硬化を必要回数だけ行っ て，1層目の樹脂を設計した形状に硬化させる.

次に, 図 1(a)，(b)て硬化させた 1 層目の混合物の上 に樹脂と短䋐維の混合物を薄く積層させる. この混合 物に対して図 1(dのようにレーザービーム描画によっ て所望の形状に樹脂を硬化させる，このように，必要 な層の数だけ積層した後, 未硬化の樹脂を取り除くと,
Table 1 Characteristics of short fiber

\begin{tabular}{|l|l|}
\hline Material & $\gamma-\mathrm{Fe}_{2} \mathrm{O}_{3}$ \\
\hline Diameter $(\mu \mathrm{m})$ & 0.04 \\
\hline Length $(\mu \mathrm{m})$ & 0.32 \\
\hline Density $\left(\mathrm{g} / \mathrm{cm}^{3}\right)$ & 4.8 \\
\hline
\end{tabular}

Table 2 Characteristics of photopolymer

\begin{tabular}{|l|l|}
\hline Gel point $\left(\mathrm{mJ} / \mathrm{mm}^{2}\right)$ & 0.20 \\
\hline Viscosity $(\mathrm{Pa} \mathrm{s})$ & 0.36 \\
\hline Density $\left(\mathrm{g} / \mathrm{cm}^{3}\right)$ & 12 \\
\hline
\end{tabular}

図 1(d)のように, 短瀻維の長手軸方向が所望の方向に そろったマイクロ部品を得ることができる. 図 1 は水 平面内で短繊維を配向した例を示したが, 底面から磁 界を印加することにより，樹脂の厚さ方向にも短瀻維 を配向することができる.

一般に䋊維強化した構造物を製作する場合には, 繊 維強化材料を用意し，その材料を加工して製品を得る. これに対して本研究の方法では, 配向した短繊維で強 化した材料の創製と構造物の製作を同時に行うことに なり，製作方法の点からも特長がある. 


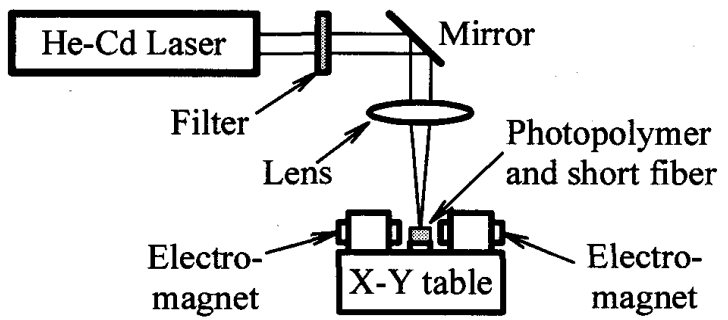

Fig. 2 Schematic diagram of experimental apparatus

End surface of the bottom

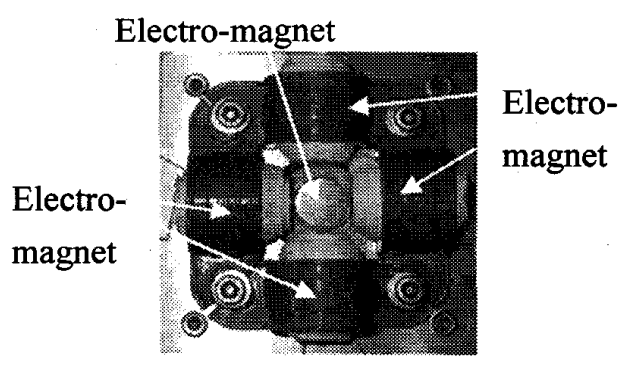

Fig. 3 Photograph of five electro-magnets

\section{3. 実験装置}

3-1 短猫椎と樹脂 本研究で使用する短繊稚と液 体樹脂の物性值をそれぞれ表 1 と表 2 に示寸．短繊維 はチタン工業（株）製の強磁生体 $\gamma-\mathrm{Fe}_{2} \mathrm{O}_{3}$ であり，紫 外線硬化樹脂は JSR（株）製 SCR751 を使用した. 造 形後, 未硬化の樹脂は（株）オリンパス工業製 EE4210 で除去した。

3 -2 造形装圆本報では, 前報(9)と同じ装置で実 験を行った．図 2 に装置全体の概略を示寸，樹脂を硬 化させる光源として, 波長 $0.325 \mu \mathrm{m}$ の $\mathrm{He}-\mathrm{Cd}$ レーザ 一を使用した. ビーム強度をフィルターで調整した後, 焦点距離 $50 \mathrm{~mm}$ のレンズで集束して造形部分に照射 した. 造形部分は X-Y テーブル上に設置してあり， テーブルを駆動することによってビーム描画を行った. ビーム直径は，計算上は $15 \mu \mathrm{m}$ である．樹脂の硬化幅 はこの値より，大きくなる.

この造形部分を上から見た写真を図 3 に示す. 図 3 の中央部分に示した底面の電磁石の端面上に液体樹脂 と磁性酸化鉄短䋊維の混合物を塗布した基板を置く. 装置は 5 個の電磁石から構成されており，基板には， 底面の電磁石之水平面内の 4 つの電磁石の合計 5 方向 から磁界を印加することができる，それぞれの電磁石 の磁界の正負方向と強度は独立に調整することができ る. 印加できる磁束密度の值は $15 \mathrm{mT}$ 程度である.

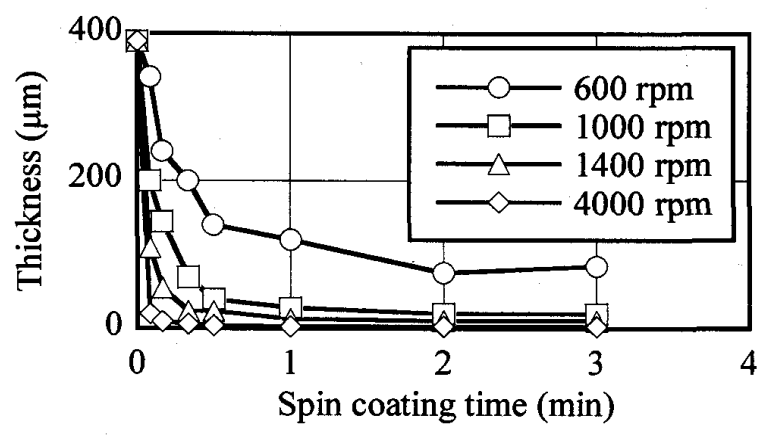

(a) Thickness and spin coating time

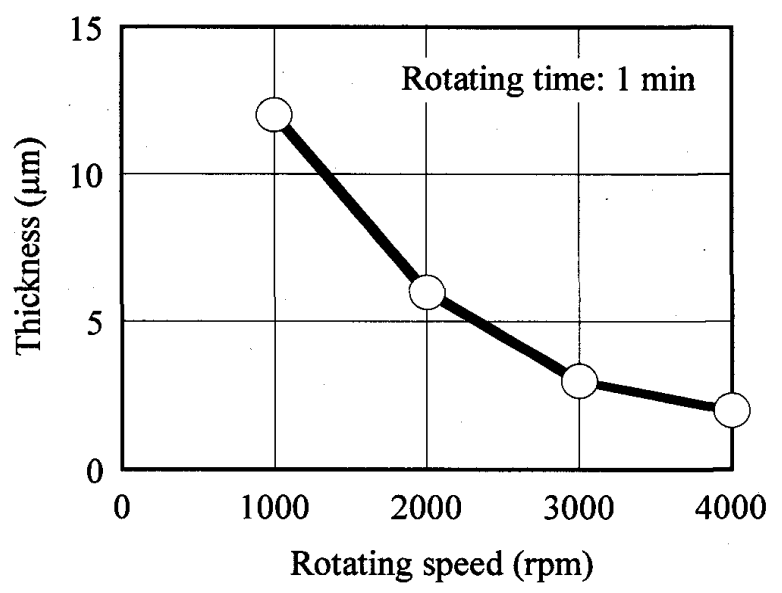

(b) Thickness and rotating speed

Fig. 4 Thickness of photopolymer by spin coating

\section{4. 実験䊅果}

4-1 樹脂の薄膜化と短㙌椎の纪向 液体樹脂を基 板に塗布し，この基板を回転させた. すなわち，スピ ンコートと同様な力法によって薄膜化した. 図 4(a)は スピンコートする時間と樹脂の厚さの測定結果である. 図より，1000 rpm 以上では，1 分ほどで樹脂の厚さは ほぼ一定となることがわかる. スピンコート時間 1 分 における回転数と厚さの関係を図 $4(\mathrm{~b})$ )に示す. 図 $4(\mathrm{~b})$ に示すように，4000 $\mathrm{pm}$ で 1 分間スピンコートを行う と, 樹脂の厚さは $2 \mu \mathrm{m}$ となる.

本研究では，短繊維と液体樹脂の混合物を薄膜化し て積層しなければならない，液体の紫外線硬化樹脂に 短瀻維を体積含有率で $0.5 \%$ 混合し，この混合物をガ ラス基板上に塗布した。 $0.5 \%$ 程度の含有率では, 図 4 の樹脂のみの場合と同じ厚さが得られた. 図 5 に短緎 維と液体樹脂の混合物の光学顕微鏡写真を示す．図 5(a)がスピンコート前であり, 図 5(b))はスピンコート 後の厚さ $2 \mu \mathrm{m}$ の混合物である. 短繊維は $10 \mu \mathrm{m}$ 程度 の大きさに凝集している，スピンコート後は, 短䋊維 


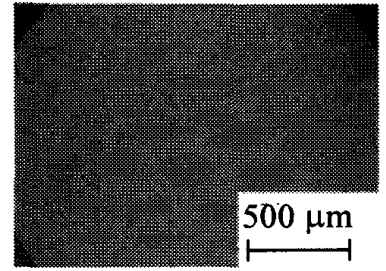

(a) Before spin coating

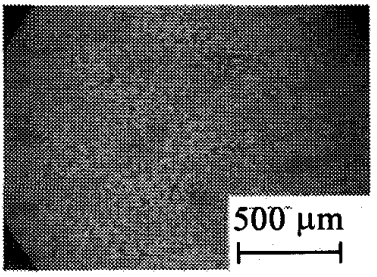

(b) After spin coating
Fig. 5 Short fibers in liquid polymer before and after spin coating (a) Before alignment

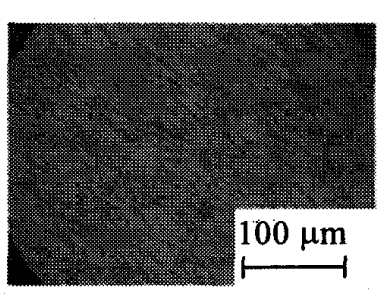

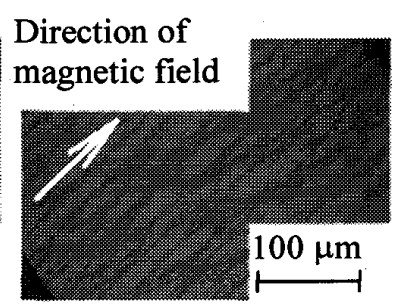

(b) After alignment
Fig. 6 Short fibers in liquid polymer before and after alignment

と樹脂の混合物が薄くなるため，写真の視野が明るい， 本実験装置で印加できる磁束密度の值は前節で述 べたように，15mT 程度である. 短緘維と液体樹脂の 混合物にこの程度の磁束密度を印加しても，短瀻維を 配向させることはできない，そこで，短瀻稚と樹脂を 塗布したガラス基板の底面から $150 \mathrm{mT}$ の磁束密度を もつ永久磁石によって混合物中の短繊維をあらかじめ 磁化し，その後，図3の装置によって配向した. この 光学顕微鏡写真を図 6 に示寸. 図 6(a) が配向前で，図 6(b)は配向後である. 配向に要する時間は数秒程度で ある．短繊維の凝集物の端部では磁界の方向と異なる 短瀻維も観察されるが，凝集物全体としては，配向し ている.

4.2 目向した薄膜の表面 本実験で用いた図 3 の 装置では，図7のように，基板の底面加ら磁界を印加 することによって，薄膜面に垂直な方向（厚さ方向） に短繊維を配向することができる，そこで，この方向 に配向した図 7(b)の表面を電子顕微鏡て観察し，短緎 維を配向させた樹脂表面の状態を検討した。

図 8(a)は，短繊維と樹脂の混合物を厚さ $2 \mu \mathrm{m}$ で硬 化して，溶剤で洗浄した後の表面の電子顕微鏡写真で ある. 表面に 10um 程度の多数の穴が観察された.こ の寸法は，図 5(b)の写真で示した短瀻維の凝集物の寸 法と同程度である.さらに，その穴の周囲に短緎維が 存在する. したがって，この穴は短繊維の凝集物が脱 落した跡であることがわかる.この状態の薄膜の厚さ

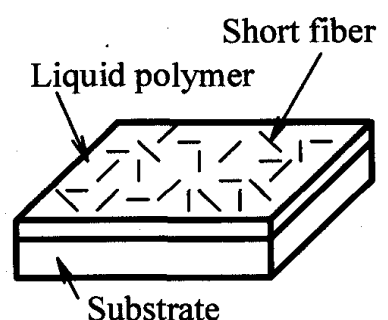

(a) Before alignment

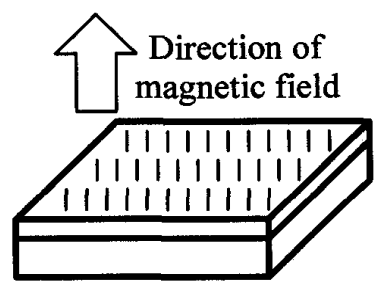

(b) After alignment
Fig. 7 Short fibers aligned perpendicular to the polymer surface

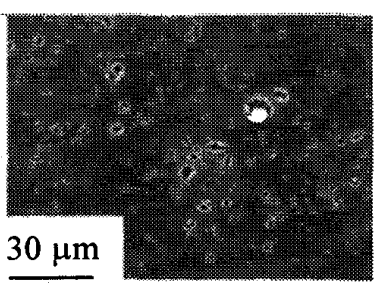

(a) Scanning electron micrograph

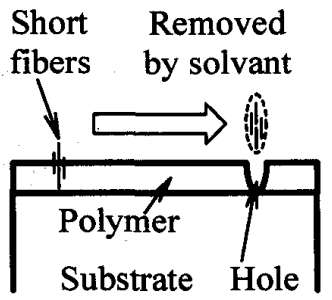

(b) Schematic diagram
Fig. 8 Surface of solidified polymer with short fibers after washing by solvent (Thickness: $2 \mu \mathrm{m}$ )

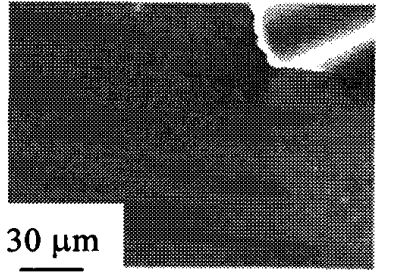

(a) Scanning electron micrograph

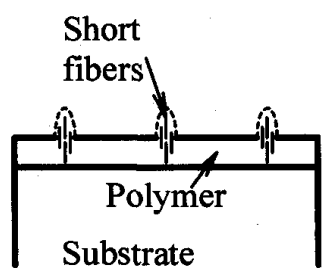

(b) Schematic diagram
Fig. 9 Surface of solidified polymer with short fibers before washing by solvent (Thickness: $2 \mu \mathrm{m}$ )

方向の断面モデルを図 $8(b)$ に示寸．液体樹脂中で短緎 維の凝集物は薄膜の厚さ方向に配向している.この混 合物に紫外線レーザーを照射して樹脂を硬化させる. しかし，短䋊維の凝集物は紫外線を透過しないため, その周辺の樹脂は硬化しない：このため，溶剂で洗浄 すると，短繊維の凝集物は脱落してしまう.

ところで，通常，光造形法では，必要な厚さまで積 層してから洗浄を行って液体樹脂を除去する．したが って図 8に示した表面が層と層の間の界面になるわけ ではなく，洗浄前の表面が界面となる，そこで，溶剂 


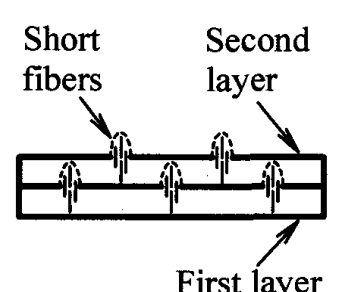

(a) Solidified the second layer on the first layer
UV light

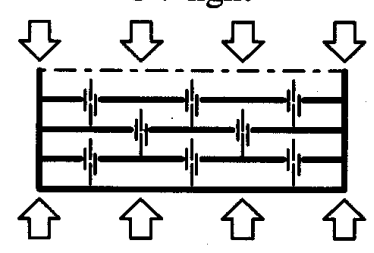

UV light

(b) Post cure by UV light after solidified all layers
Fig. 10 Post cure after manufacturing all layers

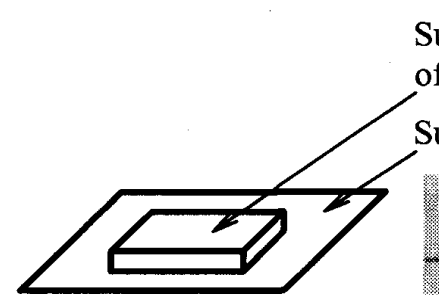

(a) Schematic diagram

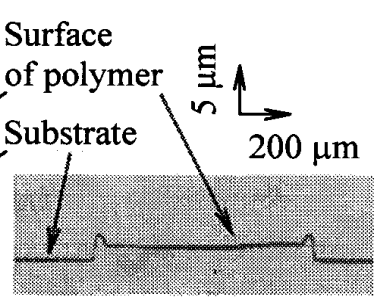

(b) Cross section
Fig. 11 Single solidified polymer layer of a square shape on a substrate

で洗浄する前の樹脂表面を観察した. この電子顕微鏡 写真を図 9(aに示す，樹脂表面に穴は観察されない。 この状態のモデルを図 9(b)に示す. 洗浄する前であり, 短瀻維は樹脂に覆われている.

このように短繊維を表面と垂直な方向に配向させ た厚さ $2 \mu \mathrm{m}$ の樹脂を, 洗浄前後について観察を行っ た. 光造形法では, 先ほど, 述べたように, 積層の工 程が完了してから溶剤を使用して未硬化の樹脂を除去 する. このため, 層と層の間の界面は図9で示したよ うに，溶剤を使用していない状態であり，配向した短 繊維の上を完全には硬化していない樹脂が覆っている. この表面の上に，図 10(a)のように，次の層が積層 されることになる. この短繊維の凝集物の周囲の樹脂 は完全には硬化していない，そこで，造形後，通常の 光造形と同様にポストキュアを行って，樹脂を完全に 硬化させることによって，図 10(b)のように，積層界 面を短繊維で強化した構造物を造形することが期待で きる.この強化の程度については，別途，検討したい と考えている.

4・3 程屏した榯脂の厚さ 短䋐稚を混合しない樹 脂の薄膜を硬化し，この断面形状を触針式粗さ計で測 定した結果を図 11 に示す.これは, 先ほよ゙示した図 4 の結果であり，2um の厚さが得られている. 図

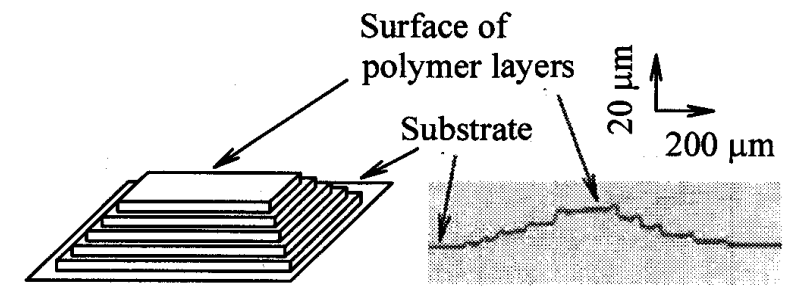

(a) Schematic diagram

(b) Cross section

Fig. 12 Solidified polymer layers of square shapes on a substrate

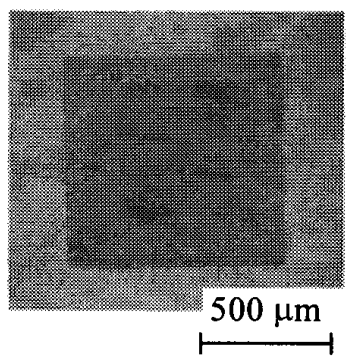

(a) Photograph

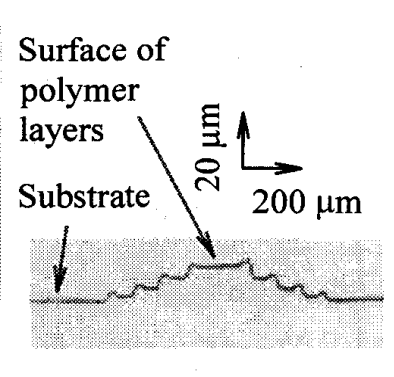

(b) Cross section
Fig. 13 Solidified polymer layers of square shapes with short fibers on a substrate

11(b)の端部が厚くなっているのは，樹脂の正方形の輪 郭から先に描画して硬化させたためである.この工程 を繰り返して，積層した形状の断面形状を図 12 に示

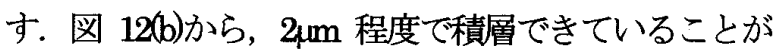
わかる. しかし，積層を重ねるごとに，層の厚さは $2 \mu \mathrm{m}$ からずれてくる.

短繊維を混合した樹脂を積層して上から見た写真を 図 13(a)に示す.この構造物では, 短繊維は配向して いない.この構造物の断面形状を図 13(b)に示す. $0.5 \%$ 程度の短繊維の含有率では, 樹脂のみの図 12 と 同じような厚さが得られている.

\section{5. 製 作 例}

前節までで述べた検討結果を用いて，短䋊維を配向 したマイクロ歯車を造形した. その光学顕微鏡写真を 図 14(a)，(b)に示す。この歯車は(c)に示すように, 歯 の部分は半径方向に短瀻維を配向し, 内側および段付 き部分は厚さ方向に配向している.（引は 1 層目の歯 の部分に，(b)は 2 層目の段付き部分にピントを合わせ た写真である. 樹脂 1 層の厚さは $12 \mu \mathrm{m}$ である.

ところで本論文の造形物では，短纎維の体積含有率

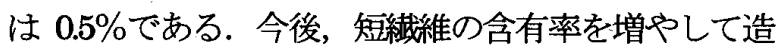
形したいと考えている. 


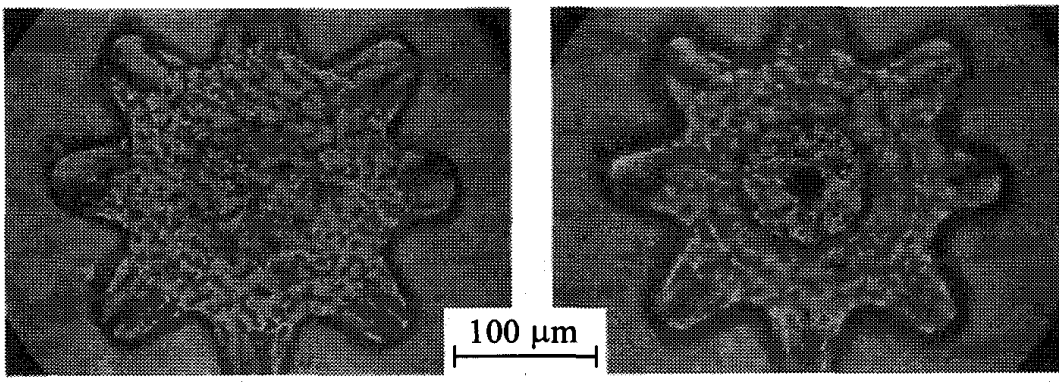

(a) Focused on the first layer

(b) Focused on the second layer

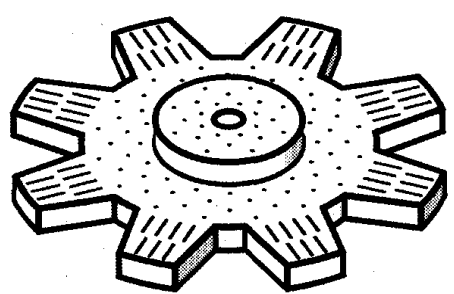

(c) Schematic diagram

Fig. 14 A micro gear reinforced by unidirectional short fibers

\section{6. 結}

本研究で得られた結論を以下に記す。

（1）数 $\mu \mathrm{m}$ の厚さの樹脂中で, 強磁性体の短繊維を磁 界の印加によって配向した.

（2）短繊維を配向した樹脂表面を観察した．積層によ り，その界面を強化できる可能性を示した.

（3）配向した短繊維で強化した樹脂層を積層したマイ クロ構造物を製作した.

\section{謝辞}

本研究を遂行するにあたり，磁性酸化鉄を御供与い ただいたチタン工業（株）に感謝の意を表する．なお， 本研究の一部は財団法人天田金属加工機械技術振興財 団平成 21 年度一般研究開発助成（レーザプロセッシ ング）によって行われたことを付記する.

\section{春考文献}

(1) Yamaguchi, K., et al, Manufacturing of Micro Structures by Using UV Sensitive Photopolymer (3rd Report, Writing with a Focused Beam) (in Japanese), Transactions of the Japan Society of Mechanical Engineers, 61-581(C)(1995), 304-310.

(2) Nakamoto, T., et al, Manufacturing of Micro Structures by Using UV Sensitive Photopolymer (4th Report, Manufacturing of 3-Dimensional Microstructures by Writing with a Focused Beam) (in Japanese), Transactions of the Japan Saciety of Mechanical Engineers, 62-594(C) (1996), 677-682.

(3) Maruo, S. and Ikuta, K., Submicron Stereolithography for the Production of Freely Movable Mechanisms by using Single-photon Polymerization, Sensors and Actuators $A$, $100,(2002), 70-76$.

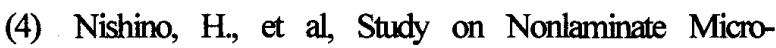
stereolithography using LCD Mask (2nd Report) - Thin Layer Laminating Fabrication using LCD Live-motion
Mask - (in Japanese), Journal of the Japan Society for Precision Engineering, 69-10 (2003), 1417-1422.

(5) Lee, D., et al, Study on LCD Micro Stereolithography using Ceramic Nanoparticles Reinforced Photosensitive Resin (in Japanese), Journal of the Japan Society for Precision Engineering, 71-11 (2005), 1415-1420.

(6) Kirihara, S., et al, Electromagnetic Wave Diffractions in Ceramic / Polymer Photonic Crystals with Three Dimensional Diamond Structure (in Japanese), Journal of the Ceramic Society of Japan, 111 - 7 (2003), 471 - 478.

(7) Zak, G., et al, Layered Manufacturing of FiberReinforced Composites, Transactions of the ASME Journal of Mamufacturing Science and Engineering, 121 (1999), 448- 456.

(8) Haberer, M., et al, Design of a Slot - Coater Based Layered - Composites Manufacturing System, Transactions of the ASME Journal of Mamufacturing Science and Engineering, 125(2003), 564-576.

(9) Nakamoto, T., and Matsuzaki K., Micro Part Reinforced by Addition of Unidirectional Short Fibers in Laser Photolithography by Applying Magnetic Field (Manufacturing Apparatus and Alignment of Short Fibers) (in Japanese), Transactions of the Japan Saciety of Mechanical Engineers, 73-729(C)(2007), 1598- 1604.

(10) Kawai, T. and Kimura, T., Magnetic Orientation of Isotactic Polypropylene, Polymer, 41- 1 (2000), 155 159.

(11) Kimura, T., et al, Magnetic Orientation of Poly (Ethylene Terephthalate), Pohymer, 41-2 (2000), 809-812.

(12) Kawai, T., et al, Crystal Orientation of $\beta$ - phase Isostatic Polypropylene Induced by Magnetic Orientation of $\mathrm{N}$, N'- dicyclohexyl -2,6 - naphthalenedicarboxamide, Pohymer, 43-26 (2002), 7301-7306.

(13) Kaneko, Y., et al, A Novel Method for Fixing the Anisotropic Orientation of Dispersed Organic Nanocrystals in a Magnetic Field, Advanced Moterials, 17-2 (2005), 160-163. 